\section{Comparison of Gel Matrices for Resolving PCR-amplified DNA Fingerprint Profiles}

\section{Guohao He, ${ }^{1}$ C.S. Prakash, ${ }^{1}$ Robert L. Jarret, ${ }^{2}$ Sadik Tuzun, ${ }^{3}$ and Jiansheng Qiu ${ }^{3}$}

\begin{abstract}
${ }^{1}$ Plant Molecular and Cellular Genetics Lab, School of Agriculture and Home Economics, Tuskegee University, Tuskegee, Alabama 36088-1614; ${ }^{2}$ USDA/ARS, Plant Introduction Station, Griffin, Georgia 30223; ${ }^{3}$ Department of Plant Pathology, Auburn University,
\end{abstract} Alabama 36849
Agarose is the preferred matrix for resolving DNA fragments resulting from PCR amplifications using arbitrary primers for the detection of random amplified polymorphic DNA (RAPD) markers. ${ }^{(1)}$ However, when multiple DNA fragments of similar sizes are generated, as is often the case in DNA amplification fingerprinting (DAF), agarose may be inefficient in adequately resolving DNA fragments. DAF differs from traditional PCR in that it employs 8-mer primers, uses less stringent annealing conditions, and results in the amplification of multiple bands with varying intensity. ${ }^{(2)}$ Well-resolved DNA fragments facilitate accurate comparisons of banding profiles among lanes. The original protocol for DAF describes the use of polyacrylamide for separation of DNA fragments and employs a silver-staining procedure to visualize the DNA. ${ }^{(2)}$ Here, we compare the gel matrices-agaroses, polyacrylamide, and vinyl polymer of polyacrylamide - for their ability to efficiently resolve the products of DAF.

Total genomic DNA from sweet potato (Ipomoea batatas) and its wild relative (Ipomoea trifida, 2X) was extracted using the hexadecyltrimethylammonium bromide (CTAB) as described by Wilson et al. ${ }^{(3)}$ Amplifications were performed in $25-\mu l$ reaction mixes containing template DNA (175 ng), single primer (5'-TGTCCTCG or $5^{\prime}$ ACGGGTGC; $6.0 \mu \mathrm{M}), \mathrm{MgCl}_{2}(5 \mathrm{~mm})$, dNTPs $(200 \mu \mathrm{M}$ each), and 5 units of truncated AmpliTaq DNA polymerase (the Stoffel fragment; Perkin-Elmer Cetus) with $1 \times$ reaction buffer supplied by Perkin-Elmer Cetus. ${ }^{(2)}$ Reaction mixtures were overlaid with two drops of mineral oil, heated to $96^{\circ} \mathrm{C}$ for $10 \mathrm{~min}$, and subjected to 35 cycles of $96^{\circ} \mathrm{C}(5 \mathrm{sec}), 45^{\circ} \mathrm{C}$ $(20 \mathrm{sec})$, and $72^{\circ} \mathrm{C}(30 \mathrm{sec})$, with a final extension step $\left(72^{\circ} \mathrm{C}\right.$ for $\left.10 \mathrm{~min}\right)$ using a Hybaid thermal cycler (National Labnet Co., Woodbridge, NJ). ${ }^{(4)}$

Reaction product aliquots from the same PCR reaction were analyzed by electrophoresis on polyacrylamide, ${ }^{(2)} \mathrm{vi}$ nyl-polymer of polyacrylamide (PCR Purity Plus, no. 550, AT Biochem, Malvern, PA), or agarose. A vertical electrophoresis system (Mini-Protean II cell; Bio-Rad, Richmond, CA) was employed to run both regular and vinyl polymer polyacrylamide gels. Polyacrylamide gels were prepared as described by CaetanoAnollés et al., ${ }^{(2)}$ and vinyl polymer of polyacrylamide $(0.7 \mathrm{~mm})$ was prepared according to the manufacturer's recommendations. Among many commercially available agarose types, Metaphor agarose (FMC Bio Products, Rockland, ME) provides a superior matrix for resolving PCR products and thus was chosen for this comparative study (G. He and C.S. Prakash, unpubl.). Agarose was tested at 3\%, and electrophoresis was performed horizontally $(11 \times 14 \mathrm{~cm})$ (Hoefer; Horizon $11 \times 14$ ). Gel and electrophoresis buffers were TBE $[100 \mathrm{~mm}$ Tris- $\mathrm{HCl}, 83 \mathrm{~mm}$ boric acid, $1 \mathrm{mM} \mathrm{Na}_{2}$ EDTA (pH 8.3)]. Following amplification, $2 \mu \mathrm{l}$ of the PCR reaction mix was combined with $1 \mu$ l of loading buffer (no. 556, AT Biochem) and loaded into the wells of the gel. Electrophoresis was conducted at $15 \mathrm{~V} / \mathrm{cm}$ (polyacrylamide gel), $25 \mathrm{~V} / \mathrm{cm}$ (vinyl polymer of polyacrylamide; PCR Purity Plus), or $6.42 \mathrm{~V} / \mathrm{cm}$ (agarose). DNA bands on polyacrylamide and vinyl polymer of polyacrylamide gels were visualized using the silverstaining procedure described by Bassam et al. ${ }^{(5)}$ with an addition of an oxidization step for 5 min using the Bio-Rad oxidizer (no. 161-0444), prior to silver staining. The agarose gel was stained with ethidium bromide $(0.5 \mathrm{mg} / 1$ for 15 min) and destained with distilled water (20 min), and bands were visualized on a UV transilluminator. Gel images were photographed using a handheld Polaroid camera with 667 film.

DNA products electrophoresed on vinyl polymer of polyacrylamide were more clearly identifiable, well separated from each other and, thus, better resolved than those on either polyacrylamide or agarose gels (Fig. $1 \mathrm{~A}-\mathrm{C}$ ). On the polyacrylamide gel, the primary or dark bands often coalesced with the secondary, fainter bands-especially those between 1.0 and $1.7 \mathrm{~kb}$ (Fig. 1B). In contrast, bands on the vinyl polymer of polyacrylamide gels were much sharper, tighter, and of uniform thickness; the primary and the secondary bands could be distinguished with relative ease (Fig. 1A). The polyacrylamide gel, however, does offer a good separation of bands of very low molecular mass $(<0.5 \mathrm{~kb})$. DNA fingerprints from primary (or dark bands) on the agarose gel were well resolved, but secondary bands do not appear clearly on the agarose gel when compared with the regular or vinyl polymer polyacrylamide gels (Fig. 1). The background fluorescence of the ethidium bromide-stained agarose gel mark- 


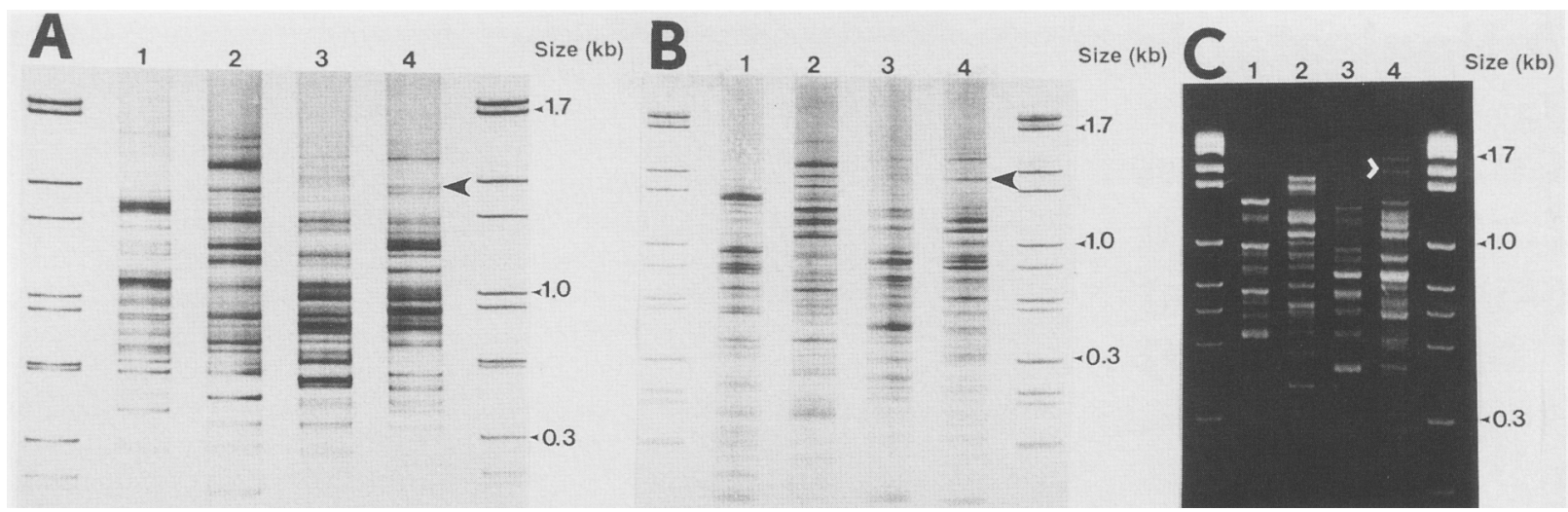

FIGURE 1 DNA amplification fingerprint products of plant DNA separated on three gel matrices: $(A)$ Vinyl polymer of polyacrylamide (PCR Purity Plus); (B) polyacrylamide; (C) agarose (Metaphor). (Lanes 1,2) PCR products using template DNA of $I$. batatas W221 and $I$. trifida, $2 \mathrm{X}$ using primer 5 '-TGTCCTCG for amplification. (Lanes 3,4) PCR products obtained from the same template DNA with primer 5'-ACGGGTGC. DNA was visualized in $A$ and $B$ by silver staining and in $C$ with ethidium bromide fluorescence on UV light. The arrowhead shows the presence of a pair of polymorphic bands that are distinct in $A$ but not in $B$ and $C$.

edly reduced the clarity of the DNA fragments, especially those of faint or secondary bands (Fig. 1C).

The improved resolution of bands run on the vinyl polymer of polyacrylamide was especially apparent with PCR fragments of near-equal molecular masses. For example, two DNA bands of $\sim 1.2 \mathrm{~kb}$ appear distinctly separate (Fig. $1 \mathrm{~A}$, lane 4 ; arrowhead) on the vinyl polymer of polyacrylamide (Fig. 1A) while they appear as one band in polyacrylamide gel (Fig. 1B ); both of these bands were hardly visible in the agarose gel (Fig. 1C). Thus, the use of vinyl polymer of polyacrylamide enables better identification of polymorphic bands than either polyacrylamide or agarose gels and, thus, may be especially useful in DNA fingerprint studies.

The electrophoresis on the vinyl polymer of polyacrylamide gel was more rapid as it was more tolerant of higher running temperatures, and this permitted the use of higher voltages. This gel is less brittle and, thus, easier to handle when compared with the polyacrylamide gel. The vinyl polymer of polyacrylamide gel swells during staining, which makes it easier to discern bands and to score polymorphisms. Gel-backed films, such as Gelbond (FMC Bio Products), can be used to support the gel after staining, and backed gels can be stored for long periods without any distortion of lanes.

Our studies show that vinyl polymer of polyacrylamide provides an improved resolution of PCR amplification products for DNA fingerprinting. This matrix permits rapid electrophoresis of DNA fragments and facilitates better detection of polymorphic DNA bands.

\section{ACKNOWLEDGMENTS}

We thank Dr. Peter Gresshoff and Dr. Caetano-Anollés of the University of Tennessee for advice on DAF. We thank Mr. Thomas Martin for photography. Contribution no. 223 was from the George Washington Carver Agricultural Experiment Station, Tuskegee University. Research was supported by grants from the U.S. Agency for International Development under the Historically Black Colleges and Universities program (PCE5053-G-00-2033-00), U.S. Department of Agriculture/Cooperative State Research Service (ALX-TU-SP01), and National Aeronautics and Space Administration (NAGW-2940). The use of trade names in this publication does not imply endorsement of the product.

\section{REFERENCES}

1. Williams, J.G.K., A.R. Kubelik, K.J. Livak, J.A. Rafalski, and S.V. Tingey. 1990. DNA polymorphisms amplified by arbitrary primers are useful as genetic markers. $\mathrm{Nu}$ cleic Acids Res. 18: 6531-6535.

2. Caetano-Anollés, G., B.J. Bassam, and P.M. Gresshoff. 1991. DNA amplification fingerprinting using very short arbitrary oligonucleotide primers. BioTechnology 9: 553-557.

3. Wilson, H.D., J. Doebly, and M. Duvall. 1992. Chloroplast DNA diversity among wild and cultivated members of Cucur- bita (Cucurbitaceae). Theor. Appl. Genet. 84: 859-865.

4. Yu, K. and K.P. Pauls, 1992. Optimization of the PCR program for RAPD analysis. Nucleic Acids Res. 20: 2606.

5. Bassam, B.J., G. Caetano-Anollés, and P.M. Gresshoff. 1991. Fast and sensitive silver staining of DNA in polyacrylamide gels. Anal. Biochem. 196: 80-83.

Received March 7, 1994; accepted in revised form June 15, 1994. 


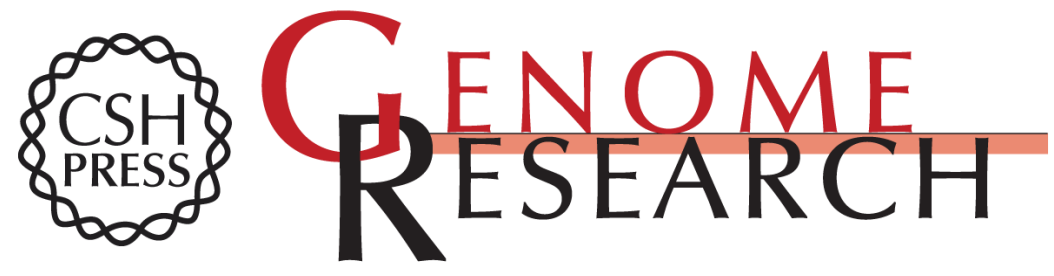

\section{Comparison of gel matrices for resolving PCR-amplified DNA fingerprint profiles.}

G He, C S Prakash, R L Jarret, et al.

Genome Res. 1994 4: 50-51

\section{License}

Email Alerting

Receive free email alerts when new articles cite this article - sign up in the box at the Service top right corner of the article or click here.

\section{Affordable, Accurate} Sequencing.

To subscribe to Genome Research go to: https://genome.cshlp.org/subscriptions 